\title{
HISTORICAL EARTHQUAKES AND TSUNAMIS OF THE SOUTH IONIAN SEA OCCURRING FROM 1591 TO 1837
}

\author{
G.A. PAPADOPOUlOS ${ }^{1}$ AND A. PLESSA ${ }^{1}$
}

\begin{abstract}
We improve the historical earthquake catalogue of the south Ionian Sea by critically reviewing twelve earthquake events occurring in the time interval 1591-1837. For some of them we complete historical information while for others we present information not taken into account in previous seismological studies. The procedure of reevaluation concluded with significant results. For example, the 5 May 1622 earthquake in Zakynthos , considered so far as a large destructive event, proved to have been only a felt event without any destructive effects, while the strong shocks of 21 August 1591 and 28 October 1766 (O.S.) are new events in the seismological literature. Tsunami phenomena reported in association with particular earthquakes also were reevaluated. It is shown that the large earthquake of 29 December 1820 in Zakynthos was not followed by a destructive tsunami flooding, as thought by previous authors, while evidence is presented that the sea-wave reportedly occurring in the Corinth Gulf in association with an aftershock of the above earthquake on 6 January 1821 very likely was not a tsunami but a storm surge that attacked the coast of Patras. The results obtained are of importance for the seismic and tsunami hazards assessment in the Ionian Sea.
\end{abstract}

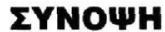

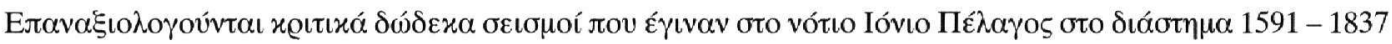

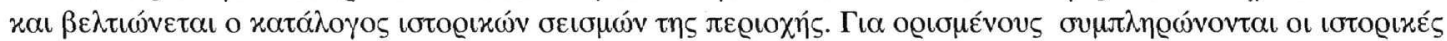

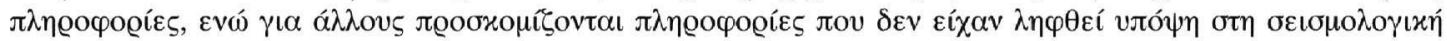

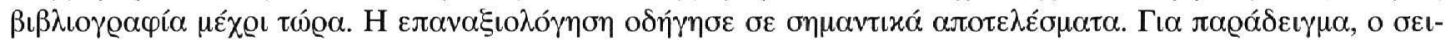

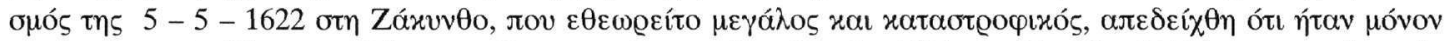

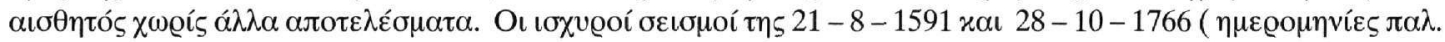

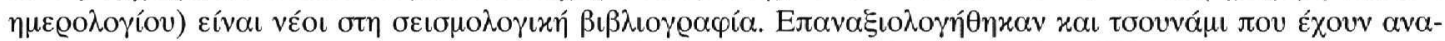

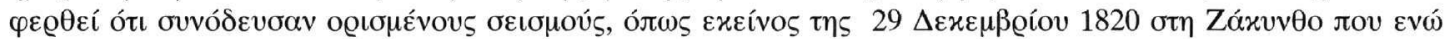

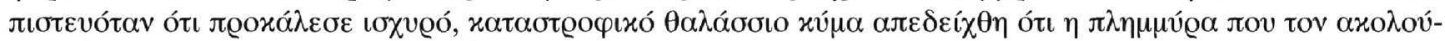

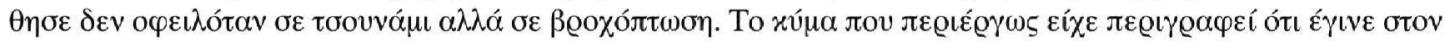

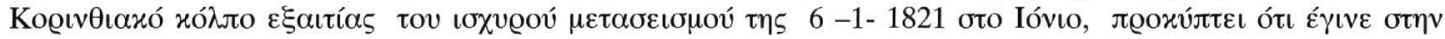

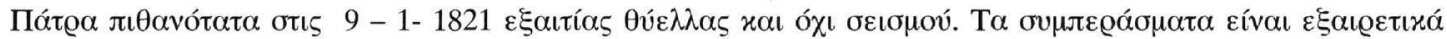

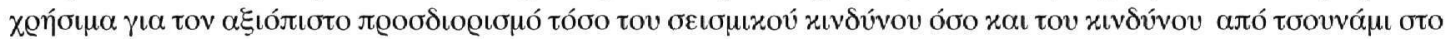
Ióvıo.

KEY WORDS: historical phenomena, earthquakes, tsunamis, Ionian Sea, documentation, reevaluation.

\section{INTRODUCTION}

It is generally recognized that the instrumental period of seismicity is too short to represent the seismic cycle of regions of even high seismic activity. Therefore, studies of seismicity, seismic hazard assessment and earthquake prediction very often suffer from the lack of statistically adequate samples of earthquake events. Attempts have been made to solve this problem by applying methods that accept incomplete earthquake files (e.g. for an application in Greece see in Papadopoulos and Kijko ,1991) and by expanding files in longer time spans with the study of pre-instrumental earthquakes.

The last years an effort started in the Institute of Geodynamics, National Observatory of Athens, for the systematic study of pre-instrumental earthquakes of Greece (e.g. Papadopoulos 2000, Papadopoulos and Vassilopoulou 2001). Here we study some earthquakes occurring in the south Ionian Sea from 1591 to 1837. On the basis of a critical review we complete and, in some cases, we present new information not taken into account

1. Institute of Geodynamics, National Observatory of Athens, P.O. box 20048, 11810 Athens, Greece 
in previous seismological studies. This procedure concluded with results of significant importance for the determination of earthquake focal parameters, which in turn becomes of importance for the seismic hazard assessment of the region. Tsunami phenomena that reportedly were associated with particular earthquakes were also reevaluated. Earthquake epicentres and geographic explanations can be found in Figure 1. The time of occurrence estimated for some earthquakes takes into account that in that period night hours were considered to start on 6 p.m.

\section{STRONG EARTHQUAKES OF THE PERIOD 1591 - 1837: A CRITICAL REVIEW}

\subsection{REVISION OF ALREADY KNOWN EVENTS}

1622: Earthquake in Zakynthos

In several studies confusion prevails since some authors attributed the effects of the 5 November 1633 Zakynthos earthquake to that of 5 May 1622 (e.g. Papazachos and Papazachou ,1989,1997) which in turn leads to determination of erroneous focal parameters. Here we investigate the original sources about the 1622 event, while the problem of confusion is analysed later, along with the examination of the 1633 case.

The author we were able to verify as the first to quote the 1622 earthquake is Chiotis $(1849$, p.29) who reported on as follows: " 5 May 1622, 4 hour at night, local, evidence coming from Varvias". No further informa-

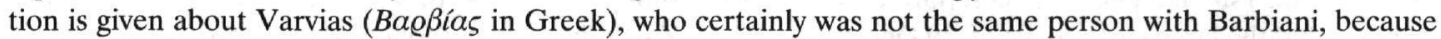
the latter is also mentioned as a source of information for other earthquakes listed by Chiotis (1849). His notice about the 1633 earthquake is: "5 November 1633 in Italy and Greece, evidence coming from p. 228 of the book of orders". It is noticeable that Chiotis (1849, p.25-26) made a remarkable distinction regarding the size of the two earthquakes by taking into account Coronelli (1762) as far as the 1633 earthquake is concerned (see below).

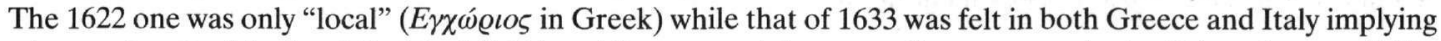
a larger size. Barbiani and Barbiani (1864, p .14), reported that according to a note in the "Livre des pr $x t s " ~ " L e$

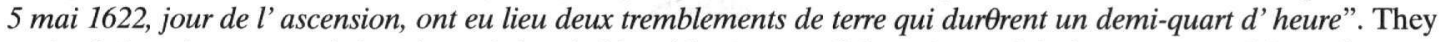
noticed that the reported duration of the shaking (demi-quart d' heure) certainly is exaggerated but they neglected to mention their source of information

We conclude that one shock, perhaps two, were felt in Zakynthos on the morning of 5 May 1622, and that the earthquake did not cause any damage, ground failures or other important macroseismic effects. It is remarkable that on 5 May 1622 at around 11a.m. a strong earthquake (Imax=VII - VIII) occurred in Slovenia (Boschi et al. , 1997). One may not exclude the possibility that the Slovenia shock was felt in Zakynthos.

\section{3: Earthquake in Zakynthos}

Girardi (1664) seems to be the first who reported on the earthquake of 5 November 1633. His passage, reproduced by Bonito (1691, p. 763), reads as follows : " $1633:$ A 5 di Novembre nell' isola del Zante fu un fierissimo Terremoto, caddero molte Case con morte di molte persone. Sibisso il Promontorio di S. Sosti, rovinarono alcune alte montagne, si apri in piu luoghi la terra, d'onde uscirono flamme, e'l mare grandemente gonsio con grandissimo spavento di tutti. Il giorno seguente il Terremoto si f $\theta$ sentire in Mantova, Verona, ed Hostiglia. Era stato ancora in Costantinopoli nel mese di Luglio un terribile Terremoto". It is clear that on 5 November 1633 a large earthquake occurred in Zakynthos causing the collapse of many houses and the death of many persons; the

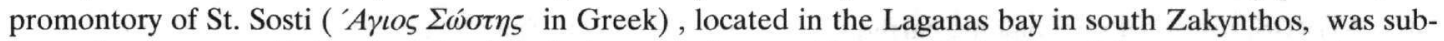
merged; moreover, high mountains failed, the ground opened in several places and flames were coming out , and the sea rose highly causing great fear to everyone. The next day an earthquake was felt in Mantova, Verona and Hostiglia. Bonito (1691) also cited a similar short description presented by Riccioli (1669) (see also a foot note made by A. Perrey in Barbiani and Barbiani ,1864, p. 14). The accounts of Chiotis $(1849,1886)$ and Barbiani and Barbiani (1864, p.14) on the 1633 earthquake were based on a short version of the Girardi's (1664) description published by Coronelli (1762) who, however, reported that the Zakynthos earthquake was felt in Mantova and in Verona (Il se fut sentir $\hat{v}$ Mantoue et $\hat{v}$ Virone). This point is of crucial importance since, in an attempt to calculate the size of the 1633 earthquake in terms of the perceptibility radii, the result would strongly depend upon the epicentral distances of shaken regions. Girardi's (1664) information that in Mantova and Verona another shock was felt the next day is likely more realistic, given the large distance between Zakynthos and those cities of north Italy, although perceptibilitiy at such a distance could not be excluded. Magniati (1688) reported on an earthquake that was felt in Mantova on 15 November 1633.

The publication of Katrames (1880) signifies the starting point of a misleading report that was followed by later authors. In fact, he did not mention at all the 1633 event and erroneously attributed its effects to the 1622 
earthquake. The same mistake was made by Zoes (1893) who, however, included in his work the 1633 event. Confusion about the effects of the 1622 and 1633 earthquakes was propagated even to modern seismological studies, e.g. Papazachos and Papazachou $(1989,1997)$ considered that both earthquakes were large events with similar macroseismic effects and estimated Richter magnitudes of 6.6 and 7.0, respectively. Lekkas et al. (1997) mentioned the confusion about the 1622 and 1633 earthquakes and suggested that only one shock occurred, that of 1633 , which certainly is not correct.

In conclusion, at all evidence the 5 November 1633 earthquake (1) was a large, destructive event causing co-seismic phenomena in the Laganas bay , such as ground failures and tsunami triggering implying high intensity (IX-X) in Zakynthos and large Richter magnitude (6.5 \pm 0.5$)$, and (2) its effects were erroneously attributed to the 1622 event.

\section{2 : Earthquake in Zakynthos}

In his historical book, Konomos (1970, p.60) reproduced an anonymous chronicle reporting an earthquake that occurred during the first days of January and certainly before 14 January 1642 (O.S.). In the seismological literature the earthquake is mentioned by Lekkas et al. (1997). The chronicle reports that the shock caused

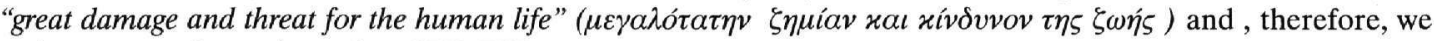
estimate a maximum intensity of VI -VII .

\section{9 : Earthquake in Zakynthos}

This is a well-known, damaging event that according to local documents (Barbiani and Barbiani, 1864) and to Venetian archives (Albini et al. , 1994) occurred on 27 or 28 June 1729. Additional information about the earthquake effects comes from the Faneromeni Code that although published by Marinos (1955) has not been

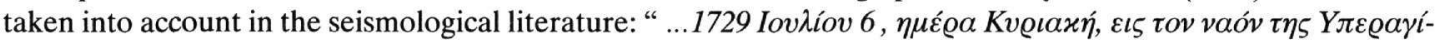

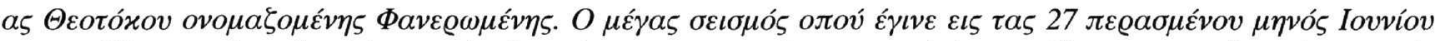

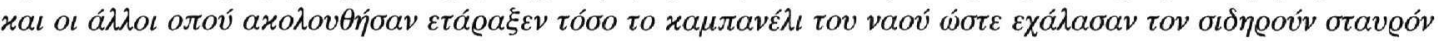

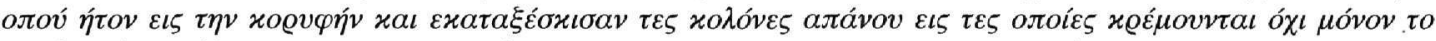

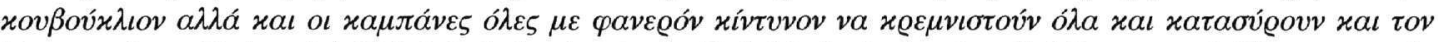

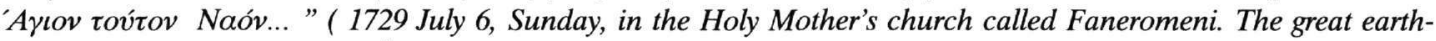
quake that occurred on the $27^{\text {th }}$ of the last month and others that followed, shaken very much the bell-tower of the church causing destruction of the iron cross on the top and tore the columns on which the canopy and the bells are hanging on, with the clear danger of collapsing and pulling down the Holy Church..."). The Code also reports that on 13 July 1729 people gathered in the church and by a majority of 86 out of 80 decided to contribute financially to the reparation of the bell-tower.

From the Faneromeni Code it also results that serious damage was caused in the Faneromeni bell-tower because of the earthquake of 14 February 1742 and possibly because of the well-known earthquake of 11 July 1767 that was destructive mainly in Cephalonia. All dates given in this section are in O.S.

\section{6 : Earthquake in Zakynthos}

De Viazi (1891), Zoes (1893) and Konomos (1970) quote a short chronicle written on 25 January 1746, indicating the occurrence of some earthquakes in Zakynthos. In the seismological literature, Lekkas et al. (1997) and Spyropoulos (1997) were based on the above information and included in their lists an earthquake occurring on that date. However, a careful reading of the chronicle makes clear that at least two remarkable earthquakes with maximum intensity IV - V were felt on 24 January 1746 at around 15:00 the first, and on 25 January 1746 at around 03:00 the second. The overall earthquake activity lasted for at least one week. The above dates are most probably in O.S.

\section{9 and 1810 : Earthquakes in Zakynthos}

In the Faneromeni Code published by Marinos (1955) there is a section that has passed unnoticed by seis-

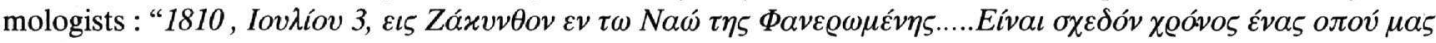

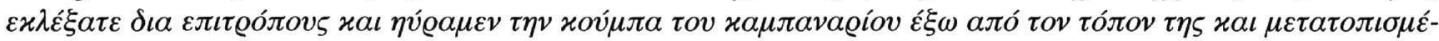

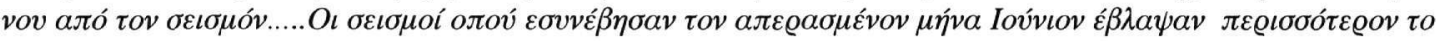

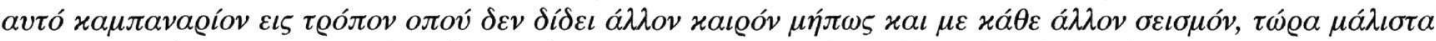

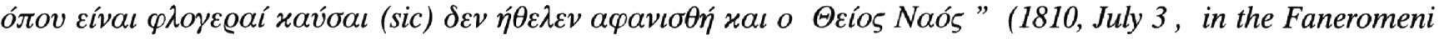
Church, Zakynthos .... It has passed nearly one year when you elected us as commissioners and we found the base of the bell-tower replaced from its normal place due to the earthquake..... The earthquakes that occurred the last June 
damaged more the same bell-tower in such a way that makes it urgent since with any future earthquake, particularly now with the hot weather, the whole church would disappear).

It becomes clear that about one year before July 1810, the bell-tower of Faneromeni was found damaged because of an unidentified earthquake. However, on the basis of unpublished evidence given by Barbiani and Mercati , Chiotis (1849, p. 26 and 30) reported on an earthquake occurring in Zakynthos on 2 June 1809 (possibly in O.S.) that caused ground fractures in the south river bank with an aperture equal to two fingeres; sulphureous evaporations followed for the rest of the year. In fact, Barbiani and Barbiani (1864) published this information which also was reproduced by others (Zoes, 1893, Lekkas et al. 1997, Spyropoulos 1997). As a consequence, the Faneromeni Code is cross-checked by independent sources. Moreover, the Faneromeni Code is also consistent with the information that earthquakes occurred in Zakynthos on June (O.S.) 1810 causing more damage to the bell-tower. In fact, Zoes (1893) and Romas (1955) supplied information from independent local archives that a strong shock occurring on 21/22 June 1810 caused collapse of houses in the main town as well as in the villages of Zakynthos.

\section{0: Tsunami ( ? ) in Zakynthos}

On 29 December 1820 (N.S.) a destructive earthquake occurred in Zakynthos. A long number of authors quoted this earthquake. Here we refer to Barbiani and Barbiani (1864), Montadon (1953), Konomos (1970) and Zoras (1973) who reproduced and / or reviewed most of the existing original documents. On 6 January 1821 a strong aftershock occurred. A slight sea disturbance and a sea-quake were reported in Zakynthos in association with the first earthquake (Barbiani and Barbiani , 1864). Some authors, however, confused the stormy weather prevailing at the time of the earthquake occurrence with a possible, destructive tsunami associating the earthquake. For example, Papazachos and Papazachou $(1989,1997)$ reported that "...6 people died and 29 were injured. Two people were drown by the flood which followed" giving the impression that the earthquake and the flooding were associated. They estimated a tsunami intensity of III + in a six-grade scale. However, from the documentation cited by Barbiani and Barbiani (1864) and Konomos (1970), it becomes clear that flooding following both the main shock of 29 December 1820 and its aftershock of 6 January 1821, as well as the reported people to be drowned after the first event, were due to a heavy rainfall. A passage from Moutzan - Martinegou (1956, p.50) , an information source never quoted so far in the seismological literature, is much illuminating

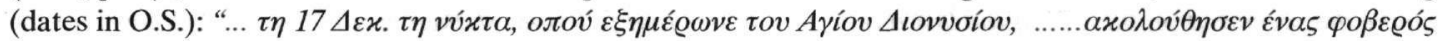

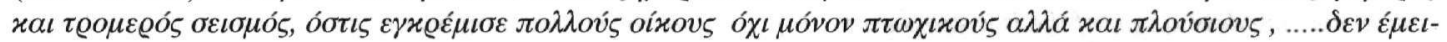

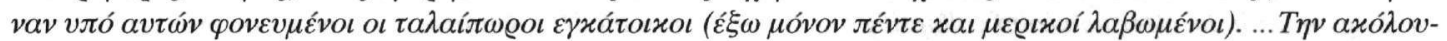

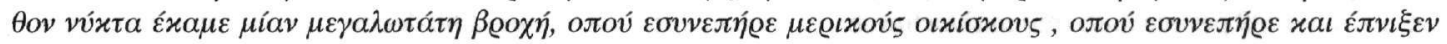

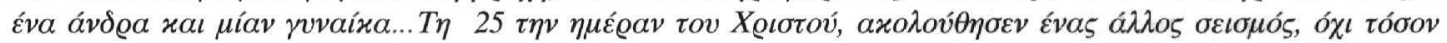

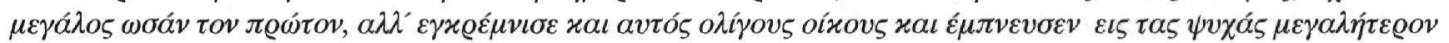

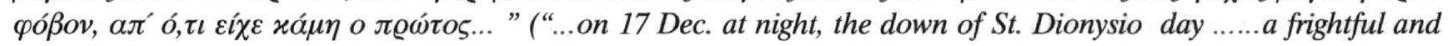
terrible earthquake happened which caused collapse of many houses not only poor but also reach ones,...... the miserable residents did not remained killed under the ruins (but only five killed and some others injured).....The next night a great raining took place that draged along some small houses and drowned one man and one woman... On $25^{\text {th }}$ the Christmas day, another earthquake followed, not so large like the first one, but it also caused collapse of a few houses and inspired greater fear in the people's soul with respect to the first one... "

We conclude that a minor sea-disturbance associated the earthquake of 29 December 1820 in Zakynthos and that the destructive flood after the earthquake was accidentally due to stormy weather.

\section{1: Tsunami (?) in Patras}

The destructive sea-wave reportedly occurring on $6^{\text {th }}$ or $9^{\text {th }}$ January 1821 in association with the 6 January 1821 aftershock remains a questionable event so far. In fact, much confusion can be found in previous catalogues regarding the time and place of its occurrence as well as of its nature. The first account found is that of Pouqueville (1824, pp. 220-222). He reported on the main shock occurring on 22 December 1820, which is an erroneous writing of the correct date of 29 December 1820, and mentioned a destructive sea-wave occurring on 9 January 1821 and attacking the province of Achaia and at the same time the sea of Alkyons Gulf, which occupies the east part of the Corinth Gulf.

Soutzo (1829) repeated in short the information given by Pouqueville (1824), including the date of 9 January 1821 for the sea-wave occurrence and the erroneous date of the 29 December 1820 earthquake. Mallet (1855), although listed the 6 January 1821 shock, reproduced Soutzo (1829) as far as the sea-wave is concerned, that is he also accepted 9 January 1821 as the date of the sea-wave occurrence. Documents reviewed by Barbiani 
and Barbiani (1864) and Montandon (1953) do not mention any sea disturbance in association with the 6 January 1821 earthquake. More recently, a long number of publications reported on a tsunami event adopting this or that time and place of occurrence without, however, making attempts to examine original documentation.

The above review is indicative of the confusion regarding the 9 January 1821 tsunami event, and shows that Pouqueville (1824) has been a source for subsequent authors. According to researchers quoted by Simopoulos (1992), Pouqueville (1824) often mixed up real and fantastic events, made mistakes and concluded with superficial evaluations. Besides, he was not in Greece during December 1820 and January 1821 and, therefore, his information is taken by other written or oral sources which unfortunately are not cited in his book. Consequently, we are facing with a description of unknown original sources, written by a writer of dubious reliability in a text that certainly contains pieces of erroneous information. A plausible evaluation of the information supplied by Pouqueville (1824) could be as follows:

Date of occurrence: There is no good reason to associate the 6 January 1821 earthquake with the sea- wave of 9 January 1821, by assuming that the date of the latter is an erroneous writing of 6 January 1821 . The date of 9 January 1821 could be accepted with less scepticism with respect to the date of 6 January 1821 as an alternative.

Place of occurrence: Pouqueville (1824) reported on the Gulf of Alkyons and the same time on the province of Achaia as well as on that the wave attacked the ancient temple of Dimitra that modern people dedicated to St. Andreas ( ... le temple antique de Ceres que les modernes ont conscre a St. Andre....) The temple is really located in Patras, that is outside the Corinth Gulf. In addition, in another book Pouqueville $(1826$, p. 408) used the reading "le golfe des Alcyons" in such a way as to include at least the entire Corinth Gulf and possibly the Gulf of Patras. Therefore, Patras could be accepted with some scepticism as the most likely place of occurrence of the sea-wave of 9 January 1821.

Nature of the event: In Pouqueville's (1824) description one may observe that the wave was associated with thunders and a storm concluding with the appearance of a rainbow, which implies that the wave was rather a storm surge than a real tsunami event.

\section{7 : Earthquake in Zakynthos}

A shock was felt in Zakynthos and Cephalonia (Schmidt, 1867) and in Peloponnese ( Mourikis ,1934) on 3 August 1837(N.S.). From two short chronicles published by Konomos (1970), and one of them by Zoes (1893), it results that a strong shock occurred on 22 July 1837 (O.S.). Lekkas et al. (1997) included it in their list. From a careful reading of the chronicles we concluded that the shock was felt at around 9 a.m. local time, that it caused a local landslide or rockfalls and that the estimated maximum intensity is V - VI.

\subsection{INFORMATION ABOUT EVENTS UNKNOWN IN THE SEISMOLOGICAL LITERATURE}

\section{1 : Earthquake in Zakynthos}

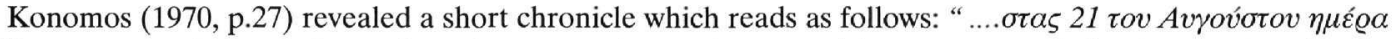

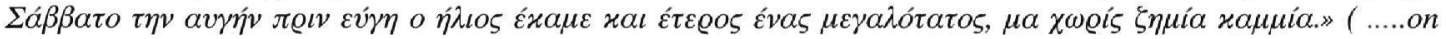
dawn of Saturday 21 August before the sunrise, another great earthquake occurred but without damage). That earthquake, possibly an aftershock of the well-known damaging earthquake of 14 April 1591 (O.S.), has not been included so far in the seismological literature. A maximum intensity of IV in the town of Zakynthos is estimated.

\section{6 : Earthquake in Zakynthos}

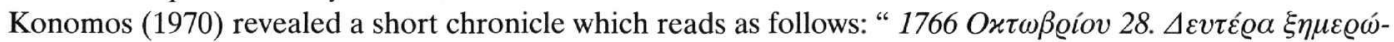

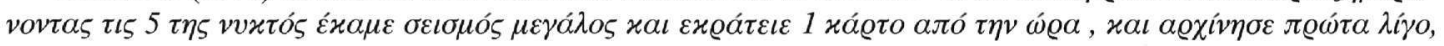

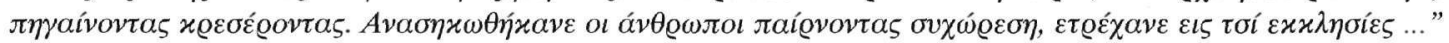
(1766 October 28 (O.S.). On Monday when it was dawning, at 5 in the night a great earthquake occurred lasting one quarter of an hour, and in the beginning it was slight and then became stronger. People were going to churches asking for forgiveness). That earthquake has not been included so far in the seismological literature. A maximum intensity of IV $-\mathrm{V}$ in the town of Zakynthos is estimated, while a local origin time of around 23:00 could be accepted with some scepticism. If this is the case, then the date should be shifted to $27^{\text {th }}$ October.

\section{6: Seaquake in South Ionian Sea}

Sieber (1817) reported that when he was sailing off SW Peloponnese suddenly the boat was shaken and 
another two shakes, less violent with respect to the first one, followed. He was told by the staff of the boat that an earthquake occurred. From Sieber's description we concluded that at all evidence the event occurred on the 28th December 1816.

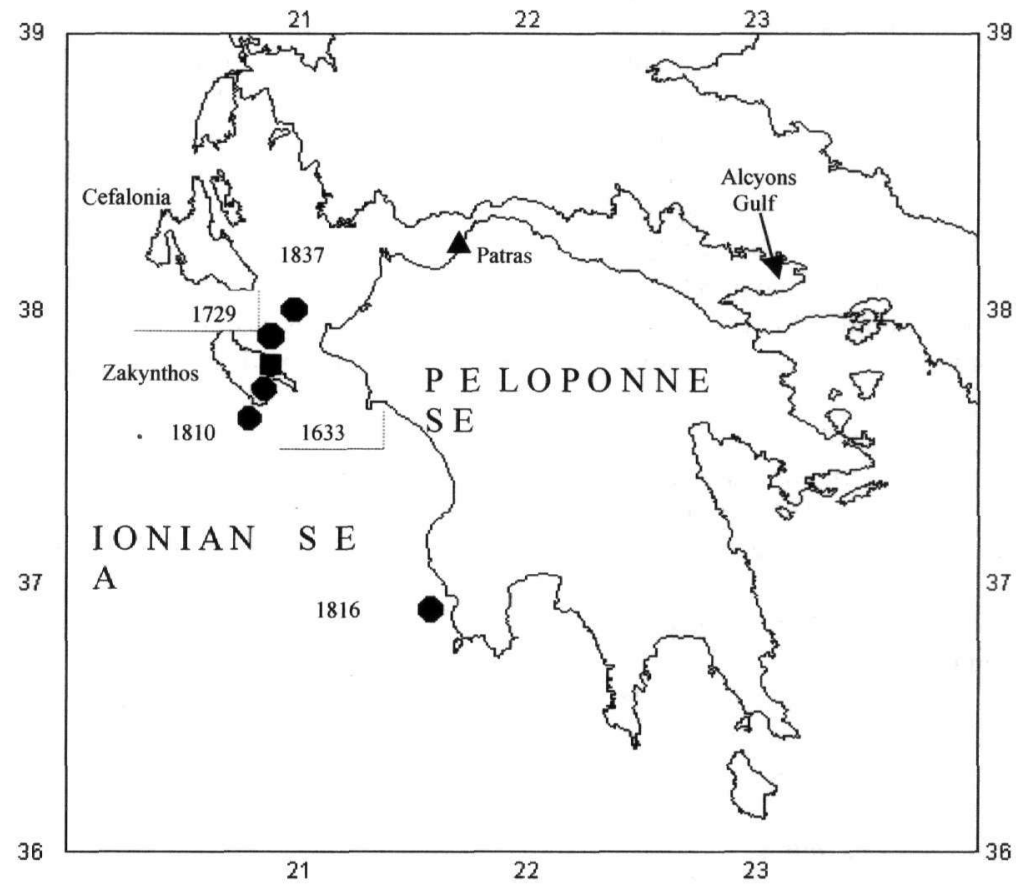

Fig. 1. Epicentres of the earthquakes listed in Table 1 (solid circles). In most cases the data available were inadequate for a reliable epicentre determination and, therefore, we indicate only the place of the maximum intensity reported, which is the city of Zakynthos (square) with coordinates $37.78^{\circ} \mathrm{N}, 20.90^{\circ} \mathrm{E}$ (see also Table 1). Triangle indicates the city of Patras.

\section{DETERMINATION OF EARTHQUAKE PARAMETERS}

Table 1 summarizes the seismic parameters determined for the earthquakes examined in this paper. It is of importance to note that for most of the events a reliable epicentral determination is impossible and, therefore, only the place of maximum intensity felt is indicated. Also, we considered somehow risky to calculate Richter magnitude restricting our calculation to only of maximum macroseismic intensity for each one of the events , with the exception of the 1633 shock whose Richter magnitude was considered to fall in the range 6.0-7.0 as the macroseismic information implies (extensive destruction, important ground failures, tsunami). In most cases times of occurrence and epicentral coordinates are roughly approximated as explained in Table 1 . Only the epicenter of the 1633 large earthquake is well determined (accuracy on the order of $10 \mathrm{~km}$ ), since ground failures described in historical documents were identified in the field (Papadopoulos, 1993; Papadopoulos and Caputo, 2001 ) in St. Sostis of the Lagana Bay, south Zakynthos, which is the adopted epicentral area in the present paper.

\section{CONCLUSIONS}

The reevaluation of historical seismicity in south Ionian Sea (1) showed that the 5 May 1622 event in Zakynthos was only a felt shock and not a large, destructive earthquake as thought in the past, ( 2 ) revealed some earthquake events unknown so far in the seismological literature, and ( 3 ) clarified that the flood following the large earthquake of 29 December 1820 in Zakynthos was not due to a tsunami wave but to heavy raining, and that the sea-wave reportedly occurring in Alkyons Gulf in association with the aftershock of 6 January 1821 was 
Table 1. Seismic parameters and remarks about the earthquakes analysed in the text. Dates are given either in Old Style (O.S.) or in New Style (N.S.) according to the information supplied by the respective original documents. Time and epicentral coordinates in parenthesis indicate only rough approximation of the respective parameter which is on the order of about \pm 1 hour for time and about $30 \mathrm{~km}$ for epicenters. When data inadequacy does not permit a reliable epicenter determination only the place of maximum intensity, that is the city of Zakynthos, is indicated by an asterisk. Intensity is given in MM scale.

\begin{tabular}{|c|c|c|c|c|c|c|c|c|}
\hline Year & Month & Day & Hour & $\varphi_{N}^{0}$ & $\lambda_{E}^{0}$ & I (MM) & Region & Remarks \\
\hline 1591 & 08 & 21(O.S.) & (04:) & $37.78^{*}$ & $20.90^{*}$ & IV & Zakynthos & $\begin{array}{l}\text { strongly felt } \\
\text { aftershock }\end{array}$ \\
\hline 1622 & 05 & 05(N.S.) & morning (?) & $37.78^{*}$ & $20.90^{*}$ & IV-V & Zakynthos & $\begin{array}{l}\text { moderate } \\
\text { shock }\end{array}$ \\
\hline 1633 & 11 & 05(N.S) & & 37.71 & 20.87 & $\begin{array}{l}\text { IX-X } \\
\text { (Richter } \\
\text { magnitude } \\
6.5 \pm 0.5 \text { ) }\end{array}$ & Zakynthos & $\begin{array}{l}\text { large, } \\
\text { destructive }\end{array}$ \\
\hline 1642 & 01 & $\begin{array}{l}\text { Before } 14 \\
(\text { O.S) }\end{array}$ & & $37.78^{*}$ & $20.90^{*}$ & VI-VII & Zakynthos & damaging \\
\hline 1729 & 06 & 27(O.S.) & morning & (37.9) & $(20.9)$ & VIII & Zakynthos & destructive \\
\hline 1746 & 01 & 24 (O.S.) & (15:) & $37.78^{*}$ & $20.90^{*}$ & IV-V & Zakynthos & strongly felt \\
\hline 1746 & 01 & 25 (O.S.) & (03:) & $37.78^{*}$ & $20.90^{*}$ & IV-V & Zakynthos & strongly felt \\
\hline 1766 & 10 & 28 (O.S.) & dawning & $37.78^{*}$ & $20.90^{*}$ & IV-V & Zakynthos & strongly felt \\
\hline 1809 & 06 & 02 (O.S.) & & $37.78^{*}$ & $20.90^{*}$ & V-VI & Zakynthos & $\begin{array}{l}\text { strong } \\
\text { shock }\end{array}$ \\
\hline 1810 & 06 & 22 (N.S.?) & $00: 30$ & $(37.6)$ & $(20.8)$ & VII-VIII & Zakynthos & destructive \\
\hline 1816 & 12 & 28 (N.S.) & (12:) & $(36.9)$ & $(21.6)$ & & Pylos & sea-quake \\
\hline 1837 & 07 & 22 (O.S.) & (09:) & $(38.0)$ & $(21.0)$ & V-VI & Zakynthos & $\begin{array}{l}\text { strong, } \\
\text { local } \\
\text { landslide }\end{array}$ \\
\hline
\end{tabular}

a storm surge occurring in the coast of Patras. The results are of significance for the seismic and tsunami hazard assessment in the Ionian Sea because they imply important changes in the catalogues of strong earthquake and tsunami events.

\section{REFERENCES}

ALBINI, P., AMBRASEYS, N.N. AND MONACHESI, G., 1994.Material for the Investigation of the seismicity of the Ionian Islands between 1704 and 1766.In: Historical Investigation of European Earthquakes, Albini, P.and Moroni, A. (Eds), vol. 2, 11-26.

BARBIANI, D.G. AND BARBIANI, B.A., 1864. Mémoire sur les tremblements de terre dans l' île de Zante. Mémoire de l' Académie Imperiale des Sciences, Dijon, 1-112.

BONITO, M., 1691, Terra tremante, o vero continuatione de' terremoti dalla creatione del mondo sino al tempo presente...(ristampa anastatica, Sala Bolognese 1980), Napoli, 1691.

BOSCHI,E. , GUIDOBONI, E. , FERRARI , G., VALENSISE , G. AND GASPERINI, P., 1997. Catalogo dei forti terremoti in Italia dal 461a.C. al 1990. Istituto Nazionalle di Geofisica /Storia Geofisica Ambiente, Roma/ Bologna , 644pp.

CHIOTIS, P., 1849. Historical memoirs of the Island of Zakynthos, vol. 1, Kerkyra, 223pp. (in Greek).

CHIOTIS, P., 1886. Historical view about earthquakes in Greece and mainly in Zakynthos, 256-259 and 274-277 (in Greek).

CORONELLI,V., 1762. Cronologia universale sacro-profana del Padre Vincenzo Coronelli, Ed. Catolica, Venezia, $516 \mathrm{pp}$.

DE VIAZI, S., 1891. Historical analects of Zakynthos, Neos Aion, $1^{\text {st }}$ year, Zakynthos 14 Dec. 1891, no 11, p. 7.

GIRARDI, G., 1664. Il Mercurio del decimosettimo secolo nel quale si contegnono I fatti più illustri succeduti nel mondo dal 1601 fino al 1650, Napoli, 1664.

KATRAMES, N., 1880. The earthquakes of Zakynthos. Philoloyika Analekta Zakynthou, Zakynthos, 459-466 (in Greek).

KONOMOS, N., 1970. Chronicles of Zakynthos (1485-1953), Athens, 1970, p.191 (in Greek). 
LEKKAS, E., KOLYVA, M., ANTONOPOULOS, G. AND KOPANAS, J., 1997. The earthquakes of Zakynthos, 78pp. (in Greek).

MAGNIATI, 1688. Notizie istoriche de' terremoti succeduti ne' secoli trascorsi e nel presente idirizzate alla Serenissima Real Maestà di Carlo II, Napoli 1688.

MALLET, R., 1855. Catalogue of recorded earthquakes from 1606 B.C. to A.D. 1850 (continued). "3rd report on the facts of earthquake phenomena (continued). Report of the 24th meeting of the British Association for the advancement of science, held at Liverpool in September 1854", 1-326, London.

MARINOS, P.I., 1955. The bell tower of the Church of Faneromeni, Eptanisiaka Fylla, 2, 7, Feb . 1955, 207-212.

MONTADON, 1953. Les tremblements de terre destructeurs en Europe, Geneve, 195pp.

MOURIKIS, M.D., 1934. The earthquakes in Greece from ancient time till now. Sarris Publ., Athens, 68 pp. (in Greek).

MOUTZAN-MARTINENGOU , E. ( 1801-1832), 1956. Autobiography, Digenis Publications (in Greek).

PAPADOPOULOS ,G.A., 1993. New developments on two disastrous historical earthquake events in western Greece. Proc. 2nd Workshop on Statistical Models and Methods in Seismology, Europ. Seismol. Comm. , Cephalonia, 2-5 June 1993, 2pp.(abstr.).

PAPADOPOULOS, G.A. (Ed.), 2000. Historical earthquakes and tsunamis in the Corinth Rift, Central Greece. National Observatory of Athens, Inst. of Geodynamics, Publ. No 12, Athens, 128pp.

PAPADOPOULOS AND KIJKO, A.,1991. Maximum likelihood estimation of earthquake hazard parameters in the Aegean area from mixed data. Tectonophysics, 185, 277-294.

PAPADOPOULOS, G.A. AND VASSILOPOULOU, A., 2001. Historical earthquakes and tsunamis in the Kythira strait. Tsunami Special Issue, Kluwer Publ., under publication.

PAPADOPOULOS ,G.A. AND CAPUTO, R., 2001. The large earthquake of 5 November 1633 in Zakynthos, Ionian Sea: historical documentation and field observations (to appear).

PAPAZACHOS, B.C. AND PAPAZACHOU, C.B., 1989. The earthquakes of Greece. Zitti Publ, Thessaloniki, 356pp (In Greek).

PAPAZACHOS, B.C. AND PAPAZACHOU, C.B., 1997. The Earthquakes of Greece. Zitti Publ., Thessaloniki, 304pp.

POUQUEVILLE, F.C.H.L., 1824. Histoire de la régénération de la Grèce comprenant le précis des évenements depuis 1740 jusqu' en 1824.Tome II, Paris Chez Firmin Didot père et fils, 613pp.

POUQUEVILLE, F.C.H.L., 1826. Voyage de la Grèce., 2ème Edition, tome 4, Chez Firmin Didot père et fils, Paris.

RICCIOLI, G.B., 1669.Chronologia riformata et ad certas conclusiones redacta, Bologna, 1669.

ROMAS, D., 1955. The plaint of Candia. Athens, 1955.

SCHMIDT, J., 1867. Study about the Kefalonia earthquake of 23 January 1867 (Ethniko Typogr., Athens),30pp.

SIEBER, F.W., 1823. Travels in the island of Crete, in the year 1817, London, 1823.

SIMOPOULOS, K., 1992. Foreign travellers in Greece, v. $\Gamma 2$, Athens, 662pp. (in Greek).

SOUTZO, A., 1829. Histoire de la revolution Greque.Chez Firmin Didot Libraire, Paris, 466pp.

SPYROPOULOS, P.J., 1997.Chronicle of the earthquakes in Greece from the ancient time till now, 453pp. (In Greek).

ZOES, L, 1893.The earthquakes of Zakynthos, Ai Mousai, A', 163-170 (in Greek).

ZORAS, G., 1973. Eptanesian studies-The earthquakes of 1820 and 1825 in Eptanisa Islands from documented description of the secret Vatican archive. Parnassos, 15, 2, 396-406 (in Greek). 